\title{
Detection of Brucella abortus in Bovine Milk by Polymerase Chain Reaction
}

\author{
Ayman Al-Mariri, Nermeen Haj-Mahmoud \\ Department of Molecular Biology and Biotechnology, Atomic Energy Commission, \\ Damascus, Syria
}

Received October 25, 2008

Accepted December 3, 2009

\begin{abstract}
This study compares milk ring test and three different polymerase chain reaction techniques (direct DNA extraction by column purification system, alkaline DNA extraction, and filtrated milk), in order to identify Brucella abortus infection in bovine milk. Milk ring test sensitivity and specificity were $72 \%$ and $80 \%$, respectively. While specificity of the three polymerase chain reaction techniques was $100 \%$; sensitivity was $92 \%, 88 \%$ and $100 \%$, respectively, for the three polymerase chain reaction procedures. We conclude that the filtered animal's milk polymerase chain reaction is the best procedure to make the diagnosis of $B$. abortus infections.
\end{abstract}

Diagnosis, milk ring test, sensitivity, specificity

Brucellosis is still one of the most common bacterial zoonoses in the Mediterranean region. The complexity of the epidemiology of brucellosis and the serious difficulties for effective control measures arise from the involvement of the main producing domestic animals (cattle, sheep, goats, camel) and humans in the infection (Boschiroli et al. 2001). This disease is caused by several species of the genus Brucella, a homogeneous group of small, non-motile, Gram-negative coccobacilli, and facultatively intracellular bacteria, belonging to the $\alpha-2$ subdivision of the Proteobacteria (Moreno et al. 2002). The predominant symptom of an acute Brucella abortus infection is reproductive failure with abortion and birth of weak offspring (Fiori et al. 2000). Transmission to humans occurs by ingestion of milk products or by direct contact with tissues and fluids of infected animals (Zvizdic et al. 2006). Milk ring test (MRT) and blood serological tests are mainly used for diagnosis of the disease. Tests for detection of $B$. abortus antibodies in milk are considered the principal methods for detecting infected herds and for diagnosing brucellosis in an individual animal (Noriello 2004). Several articles describing the application of the polymerase chain reaction (PCR) technique for amplification of universal genes of Brucella spp. have been published. This technique could be a potentially useful method for the diagnosis of brucellosis since it could detect the bacteria in paucibacillary samples and even in samples highly contaminated with other microorganisms. In addition, PCR technique could detect more infected animals compared to serological methods (Romero and Lopez-Goni 1999; Leal-Klevezas et al. 2000; Cortez et al. 2001). It has been reported that the only unequivocal method for the diagnosis of brucellosis in host is based on the isolation of B. abortus bacteria (European Commission 2002; Leyla et al. 2003) at selective medium such as Farrell's selective medium (Farrell 1974). In this study, we have tried to develop a reliable molecular procedure that could increase the sensitivity and specificity of $B$. abortus detection in bovine milk.

\section{Milk samples}

\section{Materials and Methods}

Samples of milk were collected from infected cows. Fifty positive milk samples, proved by cell culture, were received from two Syrian towns ( 35 from Hama and 15 from Homs). Each milk sample was centrifuged at $2000 \times$ $g$ for $15 \mathrm{~min}$ and the cream and deposit were spread on solid selective medium (OIE Manual 2004). Brucella $\operatorname{agar}^{\mathbb{B}}$ (BD, Spark, USA) plates with $5 \%$ sterile horse serum, polymyxin B $(5 \mathrm{U} / \mathrm{ml})$, bacitracin $(25 \mathrm{U} / \mathrm{ml})$ and

Address for correspondence:

Dr. Ayman Al-Mariri

Atomic Energy Commission Of Syria (AECS)

P.O. Box 6091

Syrian Arab Republic Damascus
Fax: 00963 - 11- 6112289

Phone: 00963 -11- 2132580

E-mail: scientific@aec.org.sy

http://www.vfu.cz/acta-vet/actavet.htm 
cycloheximide $(100 \mu \mathrm{g} / \mathrm{ml})$ were used for the isolation, identification and typing of Brucella spp. Plates were placed in an incubator for $48 \mathrm{~h}$ at $37^{\circ} \mathrm{C}$ with $10 \% \mathrm{CO}_{2}$ tension adjusted automatically. Typing of Brucella isolates was made according to the $\mathrm{CO}_{2}$ requirement, $\mathrm{H}_{2} \mathrm{~S}$ production, growth in the presence of dyes (thionine and basic fuchsin), and reaction with monospecific anti-A and anti-M sera (Alton et al. 1988).

Four millilitres of each remaining positive sample were combined for analysis by Milk ring test (MRT) and by three different polymerase chain reaction (PCR) protocols (direct DNA extraction by column purification system, alkaline DNA extraction and filtered milk). A total of 25 negative raw milk samples from healthy cows in addition to a pooled positive control were used to determine specificity.

Milk ring test (MRT)

This test was performed by adding $30 \mu \mathrm{l}$ of antigen (Institute Proquier, Montpellier, France) to $1 \mathrm{ml}$ of whole milk that had been stored for at least $24 \mathrm{~h}$ at $4{ }^{\circ} \mathrm{C}$. The height of the milk column in the tube was at least $25 \mathrm{~mm}$. A positive reaction was indicated by formation of a blue ring above a white milk column or at the interface of milk and cream. The test was considered to be negative if the color of the underlying milk exceeded that of the cream layer.

\section{Milk filtration}

Milk sample was passed onto a $0.45 \mu \mathrm{m}$ filter. Afterwards, the filter was cultured in Petri dishes (Brucella ${ }^{\circledR}$ Agar with $20 \mathrm{mg} / \mathrm{l}$ vancomycine), which were incubated at $37^{\circ} \mathrm{C}$ for $48 \mathrm{~h}$. As positive control, brucellosis culture was passed onto the filter, and cultured in a similar way as mentioned above. As negative control, we utilized milk devoid of brucellosis, for which the milk ring test and cell culture proved negative. The isolated colony of bacteria was lysed by 3 cycles of freezing-thawing. Then, $0.6 \mathrm{mg}$ of proteinase $\mathrm{K}$ was added and the bacteria were incubated for $1 \mathrm{~h}$ at $37^{\circ} \mathrm{C}$. Finally, the isolates were boiled for $10 \mathrm{~min}$.

DNA extraction (from milk)

DNA was extracted by using a $1-\mathrm{ml}$ aliquot of milk which was centrifuged at $6,000 \times g$ for $10 \mathrm{~min}$. The clear whey portion was suctioned out with a transfer pipette and discarded. The remaining milk solids and butterfat were used for DNA extraction using two different processing:

1. Direct DNA extraction by column purification system: Preheated sterile, double-distilled, deionized water was added till the sample volume reached $200 \mu \mathrm{l}$, and the mixture was vigorously vortexed to release the pellet from the bottom of the tube. A total of $25 \mu \mathrm{l}$ of proteinase $\mathrm{K}(20 \mathrm{mg} / \mathrm{ml} \mathrm{stock})$ was added, and the mixture was vortexed to mix. Subsequently, $200 \mu \mathrm{l}$ of preheated lysis buffer was added to each tube, and the contents were vortexed again until the mixture was homogeneous. The mixture was then incubated at $70{ }^{\circ} \mathrm{C}$ for $30 \mathrm{~min}$. A second aliquot of proteinase $\mathrm{K}$ was added, and the mixture was incubated at $70{ }^{\circ} \mathrm{C}$ for additional $30 \mathrm{~min}$. After incubation, $200 \mu \mathrm{l}$ of ethanol were added, the mixture was vortexed, and the samples were processed using Wizard ${ }^{\circledR}$ SV minicolumns (Wizard ${ }^{\circledR}$ SV Genomic DNA purification System, Promega, Madison, USA) as described in the product insert. DNA was eluted in $50 \mu \mathrm{l}$ of sterile, double-distilled, deionized water in all cases except where specified.

2. Alkaline DNA extraction: The alkaline extraction procedure was a modification of the method proposed by Daly et al. (2002). The milk pellet was resuspended in $1 \mathrm{ml}$ alkaline extraction solution: $(0.5 \mathrm{~mol} / 1 \mathrm{of}$ sodium hydroxide and $0.05 \mathrm{~mol} / 1$ of sodium citrate). This mixture was shaken for $10 \mathrm{~min}$ and centrifuged at $13,000 \times g$ for $5 \mathrm{~min}$. The supernatant fluid was removed and the pellet resuspended in $500 \mu \mathrm{l}(0.5 \mathrm{~mol} / \mathrm{l}) \mathrm{Tris}-\mathrm{HCl} \mathrm{pH} 8.0$, followed by centrifugation at $13000 \times \mathrm{g}$ for $5 \mathrm{~min}$. This step was repeated again. The final pellet was resuspended in $100 \mu \mathrm{l}(10 \mathrm{mmol} / \mathrm{l})$ Tris-HCl, $1 \mathrm{mmol} / 1 \mathrm{EDTA} \mathrm{pH} 8.0$, then it placed in a heating block for $1 \mathrm{~h}$ at $100^{\circ} \mathrm{C}$. The sample was then freeze-thawed twice, centrifuged at $13000 \times \mathrm{g}$ for $15 \mathrm{~min}$ and the supernatant fluid removed for PCR analysis.

PCR technique

One $\mu$ of each sample was used in PCR. The BCSP31K primers

5'-ACGCAGTCAGACGTTGCCTAT-3' and

5'-TCCAGCGCACCATCTTTCAGCCTC-3', were used to amplify a 223-bp product of the bcsp31K gene. PCR was performed in a total volume of $25 \mu \mathrm{l}$ with $1 \mu \mathrm{l}$ of the sample, 50 pmol of each primer, $50 \mathrm{mM} \mathrm{KCl,} 10$ $\mathrm{mM}$ Tris- $\mathrm{HCl}$ ( $\mathrm{pH} 9.0$ ), $0.1 \%$ Triton $\mathrm{X}-100,3 \mathrm{mM} \mathrm{MgCl}_{2}, 200 \mu \mathrm{M}$ (each) of the four nucleoside triphosphates (dNTPs), and $2.5 \mathrm{U}$ of Taq polymerase (GIBCO BRL, Inc.). The reaction was performed in a DNA thermal cycler (Applpied Bio-System) at a denaturation temperature of $94{ }^{\circ} \mathrm{C}$ for $4 \mathrm{~min}$; followed by 35 cycles at $94{ }^{\circ} \mathrm{C}$ for $60 \mathrm{~s}, 60{ }^{\circ} \mathrm{C}$ for $60 \mathrm{~s}$, and $72{ }^{\circ} \mathrm{C}$ for $60 \mathrm{~s}$ and one final extension at $72{ }^{\circ} \mathrm{C}$ for $3 \mathrm{~min}$. The amplification products were examined by electrophoresis in a $1.5 \%$ agarose gel, stained with ethidium bromide $(0.5 \mathrm{mg} / \mathrm{ml})$, visualized under UV illumination (UVTC, Inc.) at $320 \mathrm{~nm}$, and photographed.

\section{Results and Discussion}

Our study reveals that the Brucella isolates from Syrian cows belonged to B. abortus biovar 9. This biovar has already been reported in the Near East (Darwesh and Benkirane 2001; FAO 1998). 
PCR technique could identify $46 / 50$ samples when direct DNA extraction by column purification system was used, 44/50 cases when alkaline DNA extraction was used, and $50 / 50$ cases when filtered milk procedure was used, with a sensitivity of $92 \%, 88 \%$ and $100 \%$, respectively (Table 1). MRT could identify 36/50 cases, with a sensitivity of $72 \%$ only. PCR false-negative cases were $0 / 50,4 / 50,6 / 50$ and $14 / 50$ when filtrated milk procedure, direct DNA extraction by column purification system, alkaline DNA extraction and MRT was used, respectively.

Table 1. PCR and MRT results in milk samples taken from non-infected ${ }^{1}$ and infected ${ }^{2}$ animals

\begin{tabular}{|l|c|c|c|c|}
\hline Tests & Non-infected & Infected & Specificity $\%$ & Sensitivity $\%$ \\
\hline $\begin{array}{l}\text { PCR (direct DNA extraction } \\
\text { by column purification system) }\end{array}$ & $0 / 25$ & $46 / 50$ & $100 \%$ & $92 \%$ \\
\hline PCR (alkaline DNA extraction) & $0 / 25$ & $44 / 50$ & $100 \%$ & $88 \%$ \\
\hline PCR (filtrated milk) & $0 / 25$ & $50 / 50$ & $100 \%$ & $100 \%$ \\
\hline MRT & $5 / 25$ & $36 / 50$ & $80 \%$ & $72 \%$ \\
\hline
\end{tabular}

${ }^{1}$ Culture was negative on Brucella solid selective medium

${ }^{2}$ Culture was positive on Brucella solid selective medium

In Fig. 1 (Plate XIII) the amplification of $223 \mathrm{bp}$ sequence of the gene encoding the BCSP-31 antigen (lanes 4-6) as shown by the three PCR assays, ensure the presence of $B$. abortus in the examined samples. This figure reveals, in addition, the brucellosis culture that passed onto the filter (lane 3); negative control sample which represent the DNA of Yersinia enterocolitica O:9 (lane 1); and positive control sample from the DNA of $B$. abortus 544 ( lane 2). No template was added in lane 7.

All three PCR techniques results were clearly negative for all milk samples experimentally infected with Yersinia entrocolitica O:9 (data not shown).

Currently, the diagnosis of brucellosis in bovine milk sample is based almost entirely on milk ring test, which indirectly detects Brucella spp. in the host (Godfroid et al. 2002). Our results reveal that the sensitivity and specificity of this test was $72 \%$ and $80 \%$, respectively (Table 1). However, this test is limited by the milk quality and the results may be false-negative when the milk sample has low concentrations of IgM and IgA antibodies, or lacking of the fat-clustering factors (O'Leary et al. 2006). In contrast, the results may be false-positive when the milk contains colostrums and in cows vaccinated with B. abortus S19 or in those with mastitis.

There is increased interest to develop rapid and accurate (sensitive and specific) methods to detect Brucella spp. in bovine samples; and PCR procedure has been considered more sensitive and specific than serological methods (Bricker 2002; Gupta et al. 2006). Hamdy and Amin (2002) reported that PCR was a very useful procedure in the detection of the presence of wide infection in bovine milk samples. Moreover, Gupta et al. (2006) revealed that the sensitivity and specificity of PCR in detecting the presence of $B$. melitensis in goat milk were $90 \%$ and $100 \%$, respectively; and our results showed almost the same sensitivity and specificity, especially when the bacterial DNA was isolated by column purification system, $92 \%$ and $100 \%$, respectively (Table 1 ).

The extraction method of the bacterial DNA, the capacity to isolate the target bacteria, the lack of $B$. abortus colonies in some milk samples, as well as the influence of matrix components of milk could affect the sensibility and the reliability of PCR procedures (bacterial DNA isolated by column purification system, and alkaline DNA extraction). These problems were overcome in this study by passing the contaminated milk onto a 0.45 $\mu \mathrm{m}$ filter, where PCR sensibility and specificity were $100 \%$. These results were similar to the results of bacteriological detection methods which have been proven to be the most 
reliable and the only unequivocal animal brucellosis diagnostic methods (OIE 2004; GarinBastuji and Blasco 2004). In addition, this PCR procedure was more sensitive than direct PCR procedures (bacterial DNA isolated by column purification system, and alkaline DNA extraction). In conclusion, it is highly recommended to use this PCR procedure to identify Brucella in all types of milk samples. Furthermore, we advise to use this procedure as a regular screening test in farms animals.

\section{Acknowledgements}

The authors thank the Director General of AECS, and the head of the Molecular Biology and Biotechnology Department for their support. The authors also thank Dr. M. Safi for his critical reading of this manuscript.

\section{References}

Alton GG, Jones LM, Angus RD, Verger JM 1988: Techniques for the Brucellosis Laboratory. INRA. Paris.

Hamdy ME, Amin AS 2002: Detection of Brucella species in the milk of infected cattle, sheep, goats and camels by PCR.Vet J 163: 299-305

Boschiroli ML, Fouonbne V, O’Callaghan D 2001: Brucellosis: a worldwide zoonosis. Curr Opin Microbiol 4: 58-64

Bricker BJ 2002: PCR as a diagnostic tool for brucellosis. Vet Microbiol 90: 435-446

Cortez A, Scarcelli E, Soares RM, Heinemann MB, Sakamoto SM, Genovez ME, Ferreira F, Richtzenhain LJ 2001: Detection of Brucella DNA from aborted bovine foetuses by polymerase chain reaction. Aust Vet J 79 : 500-501

Daly P, Collier T, Doyls S 2002: PCR-ELISA detection of Escherichia coli in milk. Lett Appl Microb 34: 222226

Darwesh M, Benkirane A 2001: Field investigations of brucellosis in cattle and small ruminants in Syria, 19901996. Rev Sci Tech Off Int Epiz 20: 769-775

European Commission 2002: Regulation No. 535/2002 of 21 March 2002 amending Annex C to Council Directive 64/432/EEC and amending decision 2000/330/EC. Off J Eur Commun L 80: 22-28

FAO 1998: A Perspective of Brucellosis surveillance in north Africa and the Middle East: Studies in Algeria Iran - Kuwait - Morocco - Oman - Sudan and Syria. January 1998; GCP/REM/059/IFA. FAO Consultancy mission report.

Farrell ID 1974: The development of a new selective medium for the isolation of Brucella abortus from contaminated sources. Res Vet Sci 16: 280-286

Fiori PL, Mastrandrea S, Rappelli P, Cappuccinelli P 2000: Brucella abortus infection acquired in microbiology laboratories. J Clin Microbiol 38: 2005-2006

Garin-Bastuji B, Blasco JM 2004: Caprine and ovine brucellosis (excluding B. ovis). In: Manual of Diagnostic Tests and Vaccines for Terrestrial Animals, fifth ed. OIE pp. 598-606

Godfroid J, Saegerman C, Wellemans V, Walravens K, Letesson J-J, Tibor A, McMillan A, Spencer S, Sanna M, Bakker D, Pouillot R, Garin-Bastuji B 2002: How to substantiate eradication of bovine brucellosis when aspecific serological reactions occur in the course of brucellosis testing. Vet Microbiol 90: 461-477

Gupta VK, Deepak K, Vermaa PK, Routa SV, Singha and Vihana VS 2006: Polymerase chain reaction (PCR) for detection of Brucella melitensis in goat milk. Small Rum Res 65: 79-84

Leal-Klevezas DS, Martinez-Vazquez IO, Garcia-Cantu J, Lopez-Merino A, Martinez-Soriano JP 2000: Use of polymerase chain reaction to detect Brucella abortus biovar 1 in infected goats. Vet Microbiol 75: 91-97

Leyla G, Kadri G, U* Mran O 2003: Comparison of polymerase chain reaction and bacteriological culture for the diagnosis of sheep brucellosis using aborted fetus samples. Vet Microbiol 93: 53-61

Moreno E, Cloeckret A, Moriyon I 2002: Brucella evolution and taxonomy. Vet Microbiol 90: 209-227

Noriello S 2004: Laboratory-acquired brucellosis. Emerg Infect Dis 10: 1848-1850

O'Leary S, Sheahan M, Sweeney T 2006: Brucella abortus detection by PCR assay in blood, milk and lymph tissue of serologically positive cows. Res Vet Sci 81: 170-176

OIE Manual 2004: Bovine brucellosis. In: Manual of Diagnostic Tests and Vaccines for Terrestrial Animals, OIE, World Organisation for Animal Health, Part 2 (Chapter 2.3.1).

Romero C, Lopez-Goni I 1999: Improved method for purification of bacterial DNA from bovine milk for detection of Brucella spp. by PCR. Appl Environ Microbiol 65: 3735-3737

Zvizdic S, Cengic D, Bratic M, Mehantic S, Pinjo F, Hamzic S 2006: Brucella melitensis: review of the human infection case. Bosn J Basic Med Sci 6: 15-18.

WHO 2004: Brucellosis. World Health Organization Essential Medicines Library EMLib (accessed 03/12/2004) 
Plate XIII

Al-Mariri A. et al.: Detection ... pp. 277-280

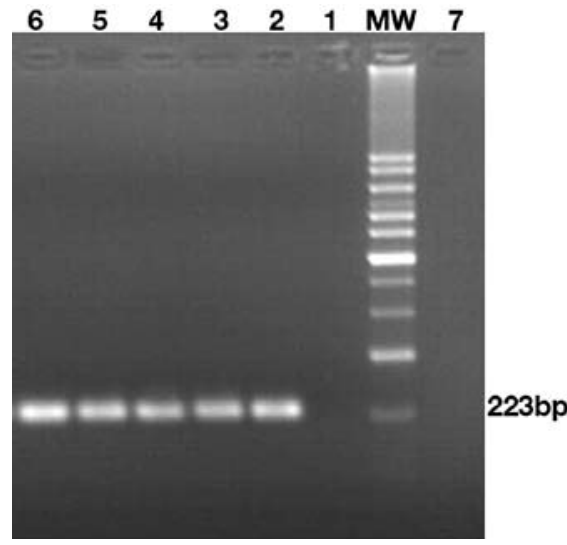

Fig. 1. Electrophoresis on 1.5\% agarose gel and ethidium bromide staining, showing the results of PCR procedures. As negative control, lane 1 for DNA isolated from Yersiunia enterocolitica O:9, and lane 7: PCR sample without template. As positive control, lane 2: DNA of B. abortus 544, and lane 3: DNA was isolated from B. abortus 544 and passed onto $0.45 \mu \mathrm{m}$ filter. Bacterial DNA isolated from contaminated milk samples using three protocols direct DNA extraction by column purification system, alkaline DNA extraction or filtrated milk onto $0.45 \mu \mathrm{m}$ filter (lanes 4-6, respectively) were used as the template in PCR reactions. Lane MW: 100-bp DNA ladder. 